\title{
Author Index Volume 12
}

Allotey, M., see Shayan, E.

$12(2015) 1550032$

Annanperä, E., Liukkunen, K. and Markkula, J., Innovation in Evolving Business Ecosystem: A Case Study of Information

Technology-Based Future Health and Exercise Service

Ar, I. M., see Yesilay, R. B.

Aronson, Z. H., An Investigation of the Role of Project Culture in

Team Efficacy and Success in Project-Based Work

Benrit, P., see Trakulmaykee, N.

Bouncken, R. B., see Pesch, R.

Bröring, S., see Golembiewski, B.

Chang, Y.-H., Lai, K.-K., Yang, W.-G. and Yang, M.-C., Note on a Heuristic Procedure to Identify the Most Valuable Chain of Patent Priority Network

Corona, L., Patenting in the University and Public Research Centers Considering Their Knowledge Profiles

Demirel, A. G. and Öner, M. A., An Exploratory Study on Operationalization of Integrated Stakeholder Relationships Management

Fazel, H., Laplume, A. O. and Muralidharan, E., Technological Innovation and Adopter Self-Construal

Fevolden, A. M., New Perspectives on Capacity Utilization: From Moving Assembly Lines to Computer-Based Control Systems

Freddi, D., see Rizzo, U.

Frenkel, A., Maital, S., Leck, E. and Israel, E., Demand-Driven Innovation: An Integrative Systems-Based Review of the Literature Gattringer, R., see Hutterer, P.

Geisler, E. and Turchetti, G., Commercialization of Technological Innovations: The Effects of Internal Entrepreneurs and Managerial and Cultural Factors on Public-Private Inter-Organizational Cooperation

Ghotb, F., see Shayan, E.

Golembiewski, B., Sick, N. and Bröring, S., Patterns of Convergence Within the Emerging Bioeconomy - The Case of the Agricultural and Energy Sector

$12(2015) 1550009$ $12(2015) 1550032$

12 (2015) 1550015

12 (2015) 1550021

$12(2015) 1550027$

12 (2015) 1550005

12 (2015) 1550029

12 (2015) 1550012

12 (2015) 1540002

$12(2015) 1540001$

$12(2015) 1550007$

$12(2015) 1550016$

12 (2015) 1550014

12 (2015) 1550030

12 (2015) 1550008

12 (2015) 1550002

12 (2015) 1550012 
Graner, M. and Mißler-Behr, M., Method Application in New Product Development and the Impact on Product Success

$12(2015) 1550019$

Hajhashem, M. and Khorasani, A., Demystifying the Dynamic of Disruptive Innovations in Markets with Complex Adoption Networks: From Encroachment to Disruption

$12(2015) 1550022$

Hall, T., Firm Boundaries and Innovation: Empirical Evidence from Entrepreneurial Finance

$12(2015) 1550023$

Harland, P. E. and Yörür, H., Decisions in Product Platform Development Projects

Hazen, B. T. and Sankar, C., Cross-Border Process Innovations: Improving the Fit Between Information Processing Needs and Capabilities

$12(2015) 1550001$

$12(2015) 1550013$

Hu, H. and Zhang, L., Catch-Up of Chinese Pharmaceutical Firms Facing Technological Complexity

$12(2015) 1550017$

Hutterer, P., Gattringer, R., Irschik, H. and Strehl, F., Managing Contradictory Stakeholder Demands of a Publicly Funded Research Center

Hyypiä, M. and Parjanen, S., Gamification as an Intervention Method in Practice-Based Innovation

Irschik, H., see Hutterer, P.

Israel, E., see Frenkel, A.

Jeurissen, W., see Van Der Sijde, P.

Karlsson, A. and Stetler, K. L., Frequency Versus Effect-Obstacles to Innovation and Their Relationship to Innovation Self-Efficacy

Kasahara, T., Strategic Technology Adoption Under Dispersed Information and Information Learning

Kässi, T., see Sarkkinen, M.

Khorasani, A., see Hajhashem, M.

Kraus, S., see Pesch, R.

Lai, K.-K., see Chang, Y.-H.

Laplume, A. O., see Fazel, H.

Leck, E., see Frenkel, A.

Liao, Y.-Y., see Wang, M.-Y.

Liukkunen, K., see Annanperä, E.

Lo, H.-C., see Wang, M.-Y.

Maital, S., see Frenkel, A.

Markkula, J., see Annanperä, E.

Masele, J. J., Towards E-Commerce Use for Pro-Poor Tourism Promotion: Local Providers' ICT Training Needs in Tanzania

Mathew, M., Introduction to the Special Section on Patent Analytics

Mathew, M., see Nair, S. S.

Mißler-Behr, M., see Graner, M.

Mpinganjira, M., Perceived Ease of Use: Examining Its Influence on Personal Use of the Tax e-Filing System

Muralidharan, E., see Fazel, H.

Nair, S. S. and Mathew, M., The Dynamics Between Forward Citations and Price of Singleton Patents

Öner, M. A., see Demirel, A. G.

$12(2015) 1550002$

$12(2015) 1550018$

12 (2015) 1550002

12 (2015) 1550008

12 (2015) 1550006

12 (2015) 1550025

12 (2015) 1550028

12 (2015) 1550004

12 (2015) 1550022

12 (2015) 1550029

12 (2015) 1540002

12 (2015) 1550016

12 (2015) 1550008

12 (2015) 1540004

12 (2015) 1550015

12 (2015) 1540004

12 (2015) 1550008

12 (2015) 1550015

12 (2015) 1550020

12 (2015) 1502001

12 (2015) 1540003

12 (2015) 1550019

12 (2015) 1550003

12 (2015) 1550016

12 (2015) 1540003

12 (2015) 1550007 
Parjanen, S., see Hyypiä, M.

Pesch, R., Bouncken, R. B. and Kraus, S., Effects of Communication

Style and Age Diversity in Innovation Teams

Ramaciotti, L., see Rizzo, U.

Rizzo, U., Freddi, D. and Ramaciotti, L., The Impact of New

Scientific Knowledge on Firms' Routines and Capabilities. The

Case of Mechatronics

Rosendaal, B., see Van Der Sijde, P.

Rundquist, J., see Song, N.

Sadabadi, A. A., see Sadeghi, M. E.

Sadeghi, M. E. and Sadabadi, A. A., Evaluating Science Parks Capacity to Create Competitive Advantages: Comparison of Pardis Technology Park and Sheikh Bahaei Science and Technology Park in Iran

Sankar, C., see Hazen, B. T.

Sarkkinen, M. and Kässi, T., Predictive Modeling of Innovation Capability in a Regional Context

Schaarschmidt, M. and Von Kortzfleisch, H., Firms' Resource Deployment and Project Leadership in Open Source Software Development

Shayan, E., Allotey, M. and Ghotb, F., Effects of "Media" on Innovation, Empirical Results

Sick, N., see Golembiewski, B.

Song, N., Zhu, J. and Rundquist, J., Knowledge Transfer Mechanisms and Global R\&D Operations in MNCs

Stetler, K. L., Creativity Just in Time? The Role of Delivery Precision in Product Development

Stetler, K. L., see Karlsson, A.

Strehl, F., see Hutterer, P.

Temel, S., see Yesilay, R. B.

Trakulmaykee, N. and Benrit, P., Investigating Determinants and Interaction Quality Effects on Tourists' Intention to Use Mobile Tourism Guide

Turchetti, G., see Geisler, E.

Van Der Sijde, P., Van Reekum, R., Jeurissen, W. and Rosendaal, B., To Adopt or Not to Adopt? The RFID Adoption Consideration by Entrepreneurs in a Purchasing Cooperative in Dutch Book Retailing

Van Reekum, R., see Van Der Sijde, P.

Von Kortzfleisch, H., see Schaarschmidt, M.

Wang, M.-Y., Lo, H.-C. and Liao, Y.-Y., Knowledge Flow Determinants of Patent Value: Evidence from Taiwan and South Korea Biotechnology Patents

Wonglimpiyarat, J., The Process of Entrepreneurial Revolution:

Case Study of the National Research University of Thailand

Yang, M.-C., see Chang, Y.-H.

Yang, W.-G., see Chang, Y.-H.
$12(2015) 1550018$

12 (2015) 1550029

12 (2015) 1550030

12 (2015) 1550030

12 (2015) 1550006

12 (2015) 1550011

12 (2015) 1550031

12 (2015) 1550031

12 (2015) 1550013

12 (2015) 1550004

12 (2015) 1550010

12 (2015) 1550032

12 (2015) 1550012

12 (2015) 1550011

12 (2015) 1550026

12 (2015) 1550025

12 (2015) 1550002

12 (2015) 1550021

12 (2015) 1550005

12 (2015) 1550009

12 (2015) 1550006

12 (2015) 1550006

12 (2015) 1550010

12 (2015) 1540004

12 (2015) 1550024

12 (2015) 1540002

12 (2015) 1540002 
Yesilay, R. B., Ar, I. M. and Temel, S., The Relationship Between Direct Government Support for R\&D and Patents in Emerging Economies: A Turkish Case Study

$12(2015) 1550021$

Yörür, H., see Harland, P. E.

12 (2015) 1550001

Zhang, L., see Hu, H.

12 (2015) 1550017

Zhu, J., see Song, N.

12 (2015) 1550011 